\title{
On the award of TMS Honorary Membership, 17 November 2004 Professor Robin Whatley - an appreciation
}

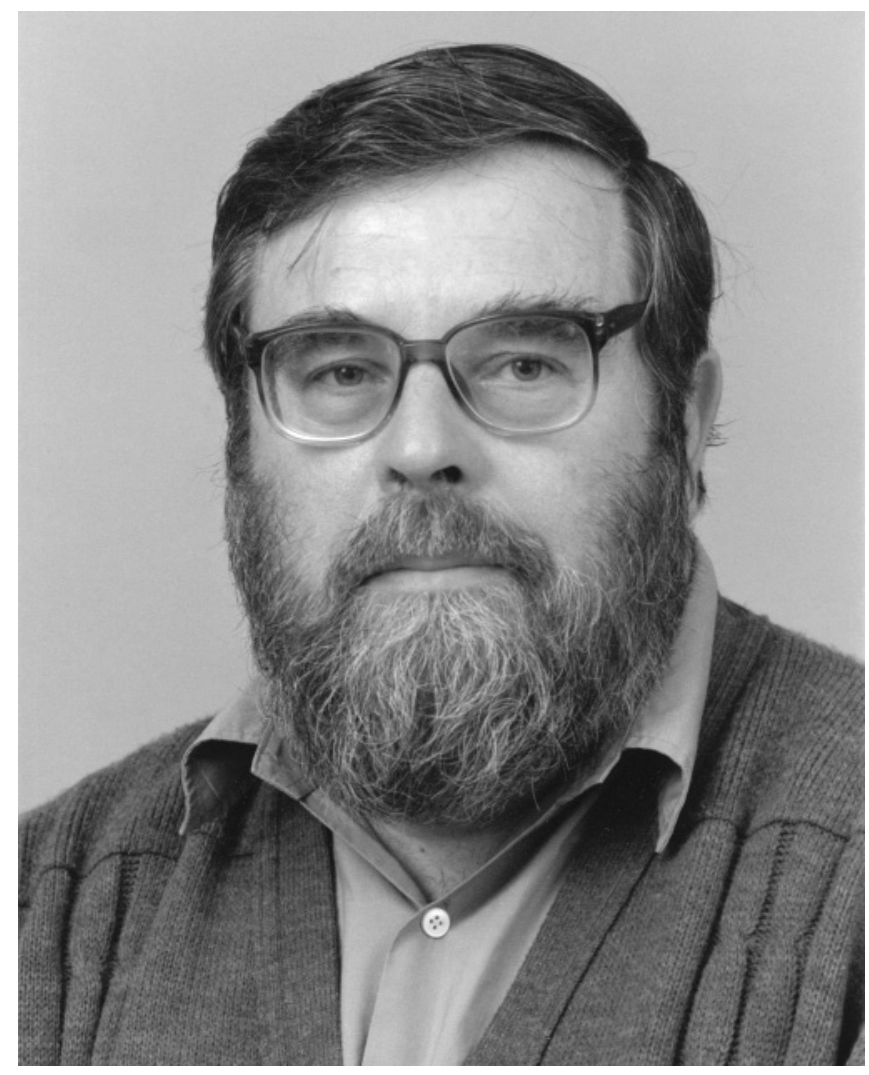

Robin Charles (Ignatius) Whatley was born a 'Man of Kent' in 1936. He was educated at Ashford Grammar School, where an inspiring teacher, Frank Kenworthy, stimulated a series of pupils to become earth scientists, for example, John Catt (University College London), Roy Clements (Leicester University), Ron Cook (recently Vice Chancellor of York University) and Chris Wilson (Open University). Following a varied postschool career as a farmer (1954), National Serviceman (19551957), and inshore fisherman based at Christchurch, Hampshire (1957-1959), Robin joined Hull University to read Geology. He graduated with a First Class Honours Degree in 1962, one of the first two ever to be awarded by the department. An interest in Micropalaeontology, in particular ostracods, became apparent during undergraduate years and formed part of his BSc dissertation. A further three years at Hull followed, funded by the Department of Scientific and Industrial Research (DSIR, forerunner of the modern research councils), leading to the award of a PhD degree in 1966 for a thesis on British Callovian and Oxfordian ostracods, carried out under the supervision of John Neale. As a mature student Robin felt it to be his duty to write stern letters to DSIR pointing out the shortcomings of its procedures and officials, and he was somewhat surprised when, visiting DSIR for a Post-Doctoral Fellowship interview, he discovered that his letters were regularly pinned to the staff notice board to be read by all. As it turned out a Fellowship was not required, as Robin was appointed Assistant Lecturer in Geology at University College of Wales, Aberystwyth in 1966.

One of us (ARL) first encountered Robin upon arriving in Hull as a Fresher in 1961, when he was in his Final Year. This was an interesting time to enter university as part of the early 1960s expansion of Higher Education, not least because many of the Final (Third) Year students were ex-National Servicemen with far more experience of the world than people straight from school. There was thus a marked range of age and especially experience across the undergraduate population. Robin was a dominant influence in the group, not least in setting and achieving high academic standards. Some of the colourful anecdotes attributed to Robin from this period will have to await his biographer. Our paths crossed again later (or rather did not cross) when ARL replaced Robin in Aberystwyth for part of the time when he was a Visiting Professor at the University of La Plata, Argentina (1971-1973).

During a long career in Aberystwyth Robin taught a wide range of subjects, from Stratigraphy to Equine Evolution, but his contribution to the (former) MSc Micropalaeontology programme, especially in relation to ostracods is of particular importance here. A succession of MSc students supervised by Robin, and research students (a conservative estimate suggests about $80 \mathrm{MScs}$ and over $40 \mathrm{PhDs}$ ) have contributed to major advances in our understanding of fossil and Recent Ostracoda under his leadership; one of us (JEW) being a member of that lineage. Robin, with Caroline Maybury, also organized the successful Xth International Symposium on Ostracoda in Aberystwyth in 1988, as well as editing the subsequent substantial volume, Ostracoda and Global Events, published under the aegis of our Society in 1990. In 1994, he followed this up by ably hosting another Society-sponsored symposium, entitled 'ODP and the Marine Biosphere', as well as editing (with Alicia Moguilevsky) a selected collection of some of the papers presented in Microfossils and Oceanic Environments (1996), which is the very model of in-house desk-top publication.

Meanwhile, Robin Whatley had risen through the University ranks, becoming Lecturer in 1967, Senior Lecturer in 1976, Reader in 1985 and, finally, receiving a well-deserved Personal Chair in 1988. During a scientific career of over forty years he has published three edited books and 279 papers (the first in 1964), with some 25 in press at the time of writing this note. This phenomenal output, mainly on post-Palaeozoic ostracods, ranges through the geological column and across the world. To single out one particular achievement, a good example is the work of Robin and generations of students on deep-sea ostracod faunas. Pioneering work by Dick Benson had focused on particular elements of the relatively sparse deep-sea assemblages 
and their carapace architecture. The work of Robin and associates, ranging over the world's ocean basins, documented the diversity and interconnections of ostracod faunas in past and present oceanic environments, thereby giving us for the first time an appreciation of the evolutionary relationships between the relatively well-documented fossil shelf assemblages and their deeper-water relatives.

The year 2000 was a bittersweet one for Robin when, after 124 years, the teaching of Geology (as a single honours subject) was discontinued at Aberystwyth, and with it went the internationally recognized MSc in Micropalaeontology. It is pleasing, however, to note that his former students took the opportunity of a Grand Reunion held in July of that year, to honour Robin and his long-time micropalaeontological colleague, John Haynes, with fitting presentations '.. in grateful thanks for your inspired teaching, supervision and many kindnesses'. It was also a relief for them to know that the Aberystwyth collections were now safe in The Natural History Museum, London.

To be a student of Robin's was certainly an 'interesting' experience. It was often an onerous undertaking too - not only could one expect some 'stick', but one would also invariably be expected to do 'extracurricular' tasks for him as well, albeit always politely prefaced by '... Be a good chap and ...'. Most students took this in good spirits, as 'part of the PhD'. On the other hand, he was a generous supervisor and loyal to his students. He liked them to keep in touch and was proud of what many had achieved in their subsequent careers.

Robin finally retired in 2001; he had taken early retirement four years earlier, only to be brought back out of the university's necessity. He continues to busy himself with ostracods and his new fishing boat. He also still maintains his connections with Argentina and is particularly proud of being made a Member of the Argentinian Academy of Sciences in 1985.

At a recent meeting, the TMS Committee felt it was now opportune that Robin's long career should be honoured in a suitable way. He had been on the Society's Committee only once (Chairman of the Ostracod Group from 1980-1983), it is true, but his lifelong contribution to micropalaeontology and the training of students had been exemplary. To quote a Committee Minute,

It was particularly this latter point which the Committee wanted to stress most as it was felt that an extremely large number of students, both at Masters and Doctoral level, had benefited so much from Robin's guidance and tuition and gone on themselves into careers in micropalaeontology.

The Micropalaeontological Society is pleased to recognize Robin Whatley's many achievements with Honorary Membership.

\section{REFERENCES}

Moguilevsky, A. \& Whatley, R. 1996. Microfossils and Oceanic Environments. University of Wales, Aberystwyth Press, 434 pp.

Whatley, R.C. 1964. The ostracod genus Progonocythere in the English Oxfordian. Revue de Micropaléontologie, 7: 188-194.

Whatley, R. \& Maybury, C. 1990. Ostracoda and Global Events. British Micropalaeontological Society Publication Series. Chapman \& Hall, London, $621 \mathrm{pp}$.

Alan R. Lord

Forschungsinstitut Senckenberg, Senckenberganlage 25, D-60325 Frankfurt-am-Main, Germany

(e-mail: Alan.Lord@senckenberg.de)

John E. Whittaker Department of Palaeontology, The Natural History Museum, Cromwell Road, London SW7 5BD

(e-mail: J.Whittaker@nhm.ac.uk) 